\title{
FIRST RECORD OF A MACRORAPTORIAL SPERM WHALE (CETACEA, PHYSETEROIDEA) FROM THE MIOCENE OF ARGENTINA
}

\author{
DAVID SEBASTIÁN PIAZZA \\ Laboratorio de Anatomía Comparada y Evolución de los Vertebrados. Museo Argentino de Ciencias Naturales \\ "Bernardino Rivadavia", Av. Angel Gallardo 470, (C1405DJR), Buenos Aires, Argentina. \\ dspiazza@hotmail.com
}

\section{FEDERICO LISANDRO AGNOLIN}

Laboratorio de Anatomía Comparada y Evolución de los Vertebrados. Museo Argentino de Ciencias Naturales "Bernardino Rivadavia", Av. Angel Gallardo 470, (C1405DJR), Buenos Aires, Argentina. Fundación de Historia Natural "Félix de Azara". Departamento de Ciencias Naturales y Antropología. Universidad Maimónides.

Hidalgo 775, Buenos Aires, Argentina. CONICET.

fedeagnolin@yahoo.com.ar

\section{SERGIO LUCERO}

División Mastozoología, Museo Argentino de Ciencias Naturales "Bernardino Rivadavia Av. Angel Gallardo 470, (C1405BDB), Buenos Aires, Argentina. CONICET.

serglucero@yahoo.com.ar

\begin{abstract}
Raptorial sperm whales of the genus Livyatan were described from the Miocene of Peru and Chile. Revision of paleontological collections resulted in the finding of isolated teeth belonging to aff. Livyatan sp. coming from Early-Middle Miocene strata from Bajo del Gualicho area, Río Negro Province, Argentina. These specimens represent the first finding of this genus in the Southwestern Atlantic Ocean and indicate that Livyatan-like forms were more widespread than previously thought. The reasons of the extinction of such predatory whales are still uncertain, but it is not improbable that it may be correlated with competition for food resources with globicephaline delphinids. This hypothesis still rests on weak evidence and should be evaluated through findings of new specimens, as well as detailed analysis of the fossil record.
\end{abstract}

Keywords: Livyatan, Macroraptorial sperm-whales, Argentina, Patagonia, Miocene.

\section{INTRODUCTION}

The record of macroraptorial stem-Physeteroidea in South America is composed by two species of the genus Acrophyseter ( $A$. deinodon and A. robustus) and the giant Livyatan melvillei, all of them from Late Miocene deposits of the Pisco Formation, Peru (Lambert et al., 2016; Bianucci et al., 2016; Di Celma et al., 2016). Gutstein et al. (2015) mentioned the possible presence of Livyatan in Chile, represented by an isolated tooth coming from the Bahía Inglesa Formation (Late Miocene/Late Pliocene). In the present contribution, we report the first record assignable to Livyatan sp. from Argentina, and we briefly discuss its palaeobiogeographical implications.

\section{MATERIAL}

Institutional abbreviations. BAR, Museo de la Asociación Paleontológica de Bariloche, San Carlos de Bariloche, Río Negro Province, Argentina; MML, Museo Municipal de Lamarque, Vertebrate Paleontology, Río Negro Province, Argentina.

Locality and geological level. The specimens were found near Puesto Picavea locality, in the Gran Bajo del Gualicho area, Río Negro Province, Argentina (Figure 1). Specimens here reported come from the Early-Middle Miocene Saladar Member of the Gran Bajo del Gualicho Formation (Reichler, 2010). Lithologically, the Saladar Member is characterized by the presence of intermixed sandstone, coquina and pelitic levels. It evidences a transgressive environment of shallow waters with an evolution of facies that changes from platform sediments to typical beach deposits (Reichler, 2010). These strata correspond to the Nodipecten sp., Venericor abasolensis and Glycymerita camaronesia biozone (del Río, 2004).

\section{SYSTEMATIC PALEONTOLOGY}

\author{
CETACEA Brisson, 1762 \\ ODONTOCETI Flower, 1867 \\ PHYSETEROIDEA Gray, 1821
}

Livyatan Lambert et al., 2010

aff. Livyatan sp. 


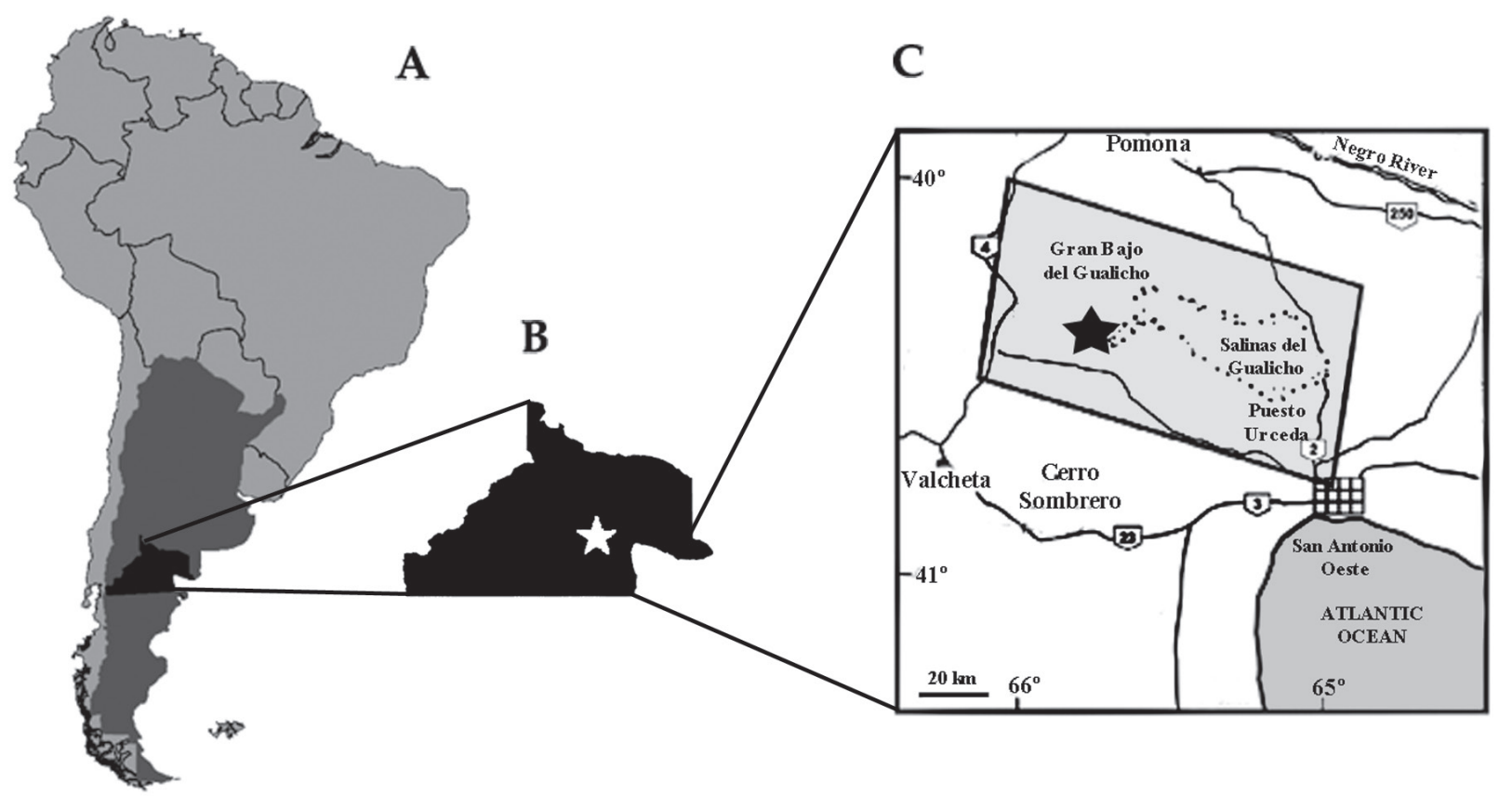

Figure 1. Map showing the location of the fossiliferous locality. A, Argentina; B, Río Negro Province, the star indicates the Bajo del Gualicho area; C, Puesto Picavea fossiliferous locality indicated by a star. Modified from Reichler (2010).

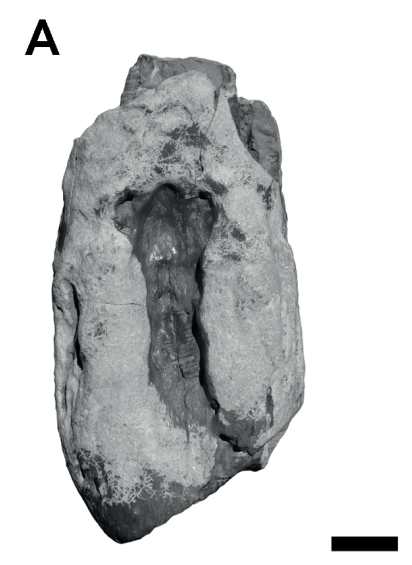

$\mathbf{E}$

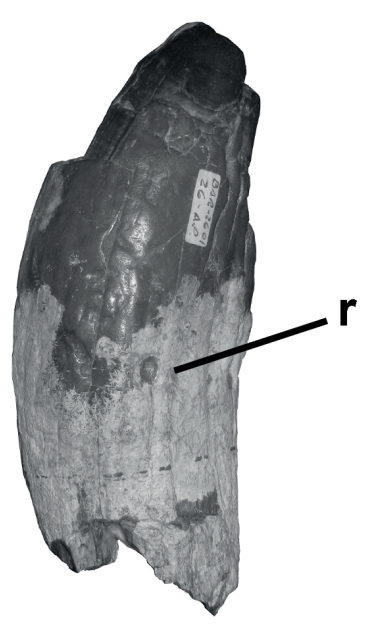

B

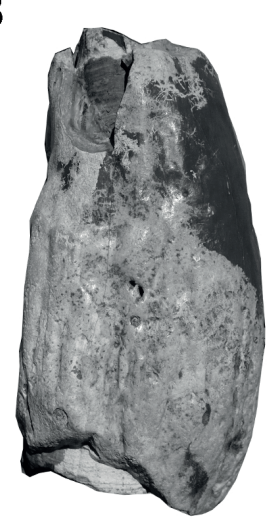

F

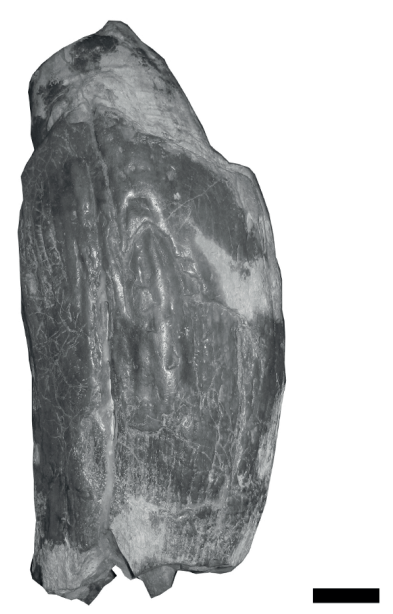

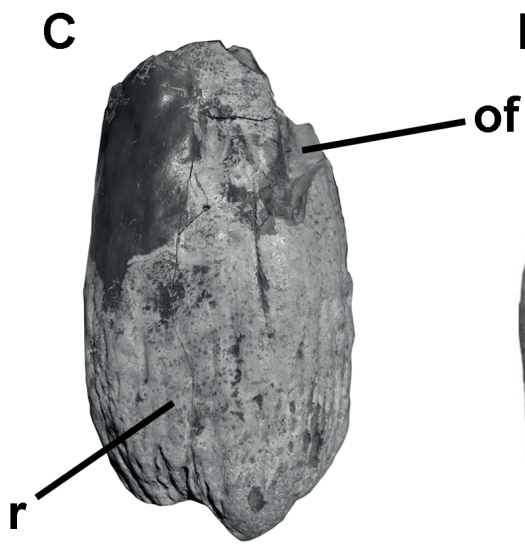

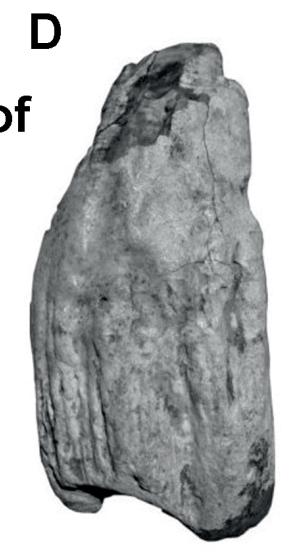

G

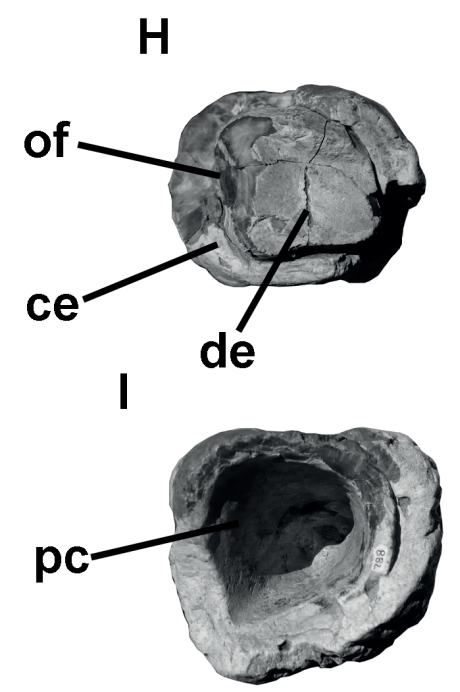

Figure 2. aff. Livyatan sp. Isolated teeth A-D, H-I, MML 882; and E-G, BAR-2601. A,C,E,F, labial/lingual; B, distal and D,G, mesial views; H, apical and I, basal views. Abbreviations: ce, cementum layer; de, dentine core; gc, gingivial collar; of, occlusal facet; pc, pulp cavity; $\mathbf{r}$, apicobasal ridges. Scale bar $=20 \mathrm{~mm}$. 
Referred material. MML 882, incomplete tooth; BAR-2601, incomplete tooth (Figure 2).

Description. Specimen MML 882 consists of an incomplete tooth lacking a large portion of the crown and the base of the root. Due to incomplete preservation, it is not possible to discern if an enamel cap was present. The root is subconical, robust and slightly distally curved. It shows a relatively thick layer of cement and a core of dentine. It is subcircular in cross-section, being slightly subrectagular at mid-height and subtriangular towards the base. The root is slightly transversely compressed and tends to converge towards its base. The pulp cavity is remarkably wide. There is a well-developed gingivial collar and an occlusal facet at the mesial margin of the tooth. The root shows apicobasal ridges, grooves, and rugosities. This ornamentation becomes attenuated from the base to the tip of the preserved portion of the element. Specimen BAR-2601 is very similar to MML 882. The only difference between the specimens is that BAR2601 lacks any indication of occlusal facets. However, this may be due to incomplete preservation.

Measurements. MML 882: Maximum apicobasal height (as preserved): $142 \mathrm{~mm}$; Maximum mesiodistal diameter: $74 \mathrm{~mm}$. BAR-2601: Maximum apicobasal height (as preserved): 178 $\mathrm{mm}$; Maximum mesiodistal diameter: $72 \mathrm{~mm}$.

\section{DISCUSSION}

\section{Taxonomic assignment of specimens}

Traditionally, isolated teeth of physeteroids were considered as being of important value, and allow referral of single elements to the specific level (see Kazár, 2002; Hampe, 2006; Pérez et al., 2011). On the other side, recent contributions suggest that isolated teeth may be not as valuable than previously thought, and are not diagnostic at the specific level, at least (Bianucci \& Landini, 2006; Lambert et al., 2016). In spite of that, we sustain that specimens here described have some morphological features that may be useful to determine their taxonomic position with some degree of certainty.
The large size of BAR-2601 and MML 882, together with the presence of an occlusion surface, indicating the presence of functional teeth in both the maxilla and the mandible, and teeth with massive, robust roots, support an attribution of these specimens to stem physeteroids (Kazár, 2002; Reumer et al., 2017). From the same locality and bed were BAR-2601 and MML 882 come, Gondar (1975) described the basal physeteroid Preaulophyseter gualichensis. This taxon differs from BAR-2601 and MML 882 in the absence of longitudinal ridges and grooves, and smaller size, among several other features.

The large size and robustness of specimens BAR-2601 and MML 882 suggest their inclusion within "macroraptorial sperm whales" (sensu Lambert et al., 2016). Among macroraptorial sperm whales, BAR-2601 and MML 882 are notably large. In fact, in most taxa, the maximum mesiodistal diameter of teeth barely exceeds $50 \mathrm{~mm}$ in size $(32 \mathrm{~mm}$ in Acrophyseter deinodon, $34 \mathrm{~mm}$ in A. robustus, $<56 \mathrm{~mm}$ in Zygophyseter varolai, $<40 \mathrm{~mm}$ in Brygmophyseter shigensis; Varola et al., 1988; Hirota \& Barnes, 1994; Bianucci \& Landini, 2006; Lambert et al., 2016). Further, in spite of the fact that BAR-2601 and MML 882 fall within the size range of Albicetus, they clearly differ from the latter in having suboval cross-section, instead of subrectangular (Boersma \& Pyenson, 2015).

On the other hand, specimens BAR-2601 and MML 882 approach in size, robustness, and cross-section Livyatan melvillei which is the cetacean with the largest known dentition, having disproportionately large teeth that are invariably larger than $80 \mathrm{~mm}$ in minimum mesiodistal diameter (Lambert et al., 2010). The combination of characters of specimens BAR-2601 and MML 882 is congruent with $L$. melvillei. However, the teeth of Livyatan have a maximum diameter between 100 and $120 \mathrm{~mm}$, the apical tooth having 81 $\mathrm{mm}$ (Lambert et al., 2010, 2016), being larger than specimens here described. Because of this, and that only isolated teeth are available, we refrain from referring BAR-2601 and MML 882 to the species level, and we choose for an open taxonomic nomenclature, referring them as aff. Livyatan sp.

Table 1. Table summarizing fossil records of macroraptorial sperm-whales.

\begin{tabular}{|c|c|c|c|}
\hline Species & Formation/Locality & Age & Author \\
\hline Acrophyseter deinodon & Pisco Fm. (Sud-Sacaco, Peru) & Late Miocene & Lambert et al. (2016) \\
\hline Acrophyseter robustus & Pisco Fm. (Cerro la Bruja, Peru) & Middle to Late Miocene & Lambert et al. (2016) \\
\hline $\begin{array}{l}\text { Zygophyseter } \\
\text { varolai }\end{array}$ & Cisterna Quarry (Apulia, Italy) & Late Miocene & Bianucci \& Landini (2006) \\
\hline Brygmophyseter shigensis & $\begin{array}{c}\text { Bessho Fm. } \\
\text { (Shiga-mura, Japan) }\end{array}$ & Early-Middle Miocene & Hirota \& Barnes (1994) \\
\hline Livyatan melvillei & Pisco Fm. (Cerro Colorado, Perú) & Late Miocene & Lambert et al. (2016) \\
\hline Livyatan melvillei & Bahía Inglesa Fm. Chile & $\begin{array}{l}\text { Late Miocene- } \\
\text { Late Pliocene }\end{array}$ & Gutstein et al. (2015) \\
\hline aff. Livyatan sp. & $\begin{array}{c}\text { Gran Bajo del Gualicho Fm., Río } \\
\text { Negro, Argentina }\end{array}$ & $\begin{array}{l}\text { Early-Middle } \\
\text { Miocene }\end{array}$ & Present contribution \\
\hline cf. Zygophyseter sp. & $\begin{array}{c}\text { Undetermined stratigraphic unit, } \\
\text { Breskens, Netherlands }\end{array}$ & ?Miocene & Reumer et al. (2017) \\
\hline
\end{tabular}




\section{Palaeobiogeographical implications}

Macroraptorial sperm whales include four different genera, namely Acrophyseter, Livyatan, Brygmophyseter and Zygophyseter (Lambert et al., 2016), and probably Albicetus (Boersma \& Pyenson, 2015). These taxa are recorded in a few localities in the Southern and Northern Hemispheres (Table 1). Among macroraptorial sperm whales, the gigantic form Livyatan is only known from Peru (Lambert et al., 2010, 2016) and Chile (Gutstein et al., 2015). It is worth mentioning that up to now the records of Livyatan correspond to sites located along the shores of the Pacific Ocean. In the present contribution, we report for the first time a form akin to the genus Livyatan from the southwestern Atlantic coast.

On the basis of the scarce fossil record, the distribution of Livyatan appears to be restricted to the Southern Hemisphere (Table 1). The absence of fossil remains of a macrophagous form of size and morphology comparable to Livyatan in the Northern Hemisphere still lacks a clear explanation. In fact, macrophagous species of the Northern Hemisphere as Zygophyseter, Brygmophyseter, and Albicetus are much smaller and with a much weaker dentition than Livyatan melvillei (Hirota \& Barnes, 1994; Boersma \& Pyenson, 2015; Lambert et al., 2016).

As noted earlier by Davies (1963), by Neogene times the equatorial warm zone constituted an important barrier in the distribution of a large number of cetaceans that have discontinuous distribution (see Bianucci et al., 2016). Based on the fossil record, it is possible that Livyatan or a comparable form was not able to cross the warm equatorial zone, and thus, did not reach the Northern Hemisphere. However, we note that the fossil record is still patchy, and more evidence is needed in order to test any hypothesis on the distribution of Livyatan and its kin.

It was inferred that gigantic raptorial sperm-whales were mysticete (baleen-whale)-predatory cetaceans, and their appearance in the fossil record coincides with a phase of diversification and size-range increase of the baleen-bearing mysticetes in the Miocene (Lambert et al., 2010). Later, by the late Pliocene, raptorial sperm whales suddenly disappear from the record (Fitzgerald, 2004; Lambert et al., 2016), and thus, by late Pliocene times, the macrophagous niche of cetaceans was probably empty. Fitzgerald (2011) described a large isolated tooth belonging to a large stem-physeteroid from the Pleistocene of Nauru Island (Pacific Ocean). However, this tooth is just $2.5 \mathrm{~cm}$ in maximum diameter, being much smaller and weaker than macroraptorial sperm whales, and is no longer considered here.

It is difficult to establish if the diversification of large predatory Globicephalinae Delphinidae by the Late MioceneEarly Pliocene could result in competition by food resources with macrophagous sperm whales. It is not improbable that giant sperm whales were ecologically replaced (Fordyce \& Muizon, 2001) or displaced by killer whales of the genus Orcinus, which have their first fossil record by the Pliocene of Italy (i.e., O. citoniensis; Pilleri \& Pilleri, 1982; Heyning $\&$ Dahlheim, 1988). Later, by Pleistocene times, Orcinus and its kin acquired a global distribution (Taylor et al., 2008).

\section{CONCLUSIONS}

Livyatan or a nearly related form is reported for the first time from the Atlantic coast of South America. This reinforces the idea that Livyatan and its kin were widespread among southern oceans during the Miocene, and suddenly disappear from the fossil record by Late Pliocene times. Its extinction is still uncertain, but it is probably related with the emergence of globicephaline delphinids. This hypothesis should be tested with finding of novel fossil material and the analysis of quantitative data.

\section{ACKNOWLEDGEMENTS}

We thank D. Cabaza, L. López (MML), and A. Méndez (BAR) for allowing us to study material under their care. Special thanks to S. Bogan and G. Lio who helped with photographs of specimens. Further, we thank J. García Marsà, J. D’Angelo, F. Brissón Egli, G. Lio, M. Aranciaga Rolando, S. Rozadilla, M. Motta, and especially F. Novas, for their help during the confection of the present contribution. Special thanks to the associate editor K.O. Porpino for his observations on the ms. We thank reviewers G. Bianucci and O. Lambert for their criticisms and thoughtful comments on the ms.

\section{REFERENCES}

Bianucci, G.; Di Celma, C.; Landini, W.; Post, K.; Tinelli, C.; De Muizon, C.; Gariboldi, K.; Malinverno, E.; Cantalamessa, G. \& Gioncanda, A. 2016. Distribution of fossil marine vertebrates in Cerro Colorado, the type locality of the giant raptorial sperm whale Livyatan melvillei (Miocene, Pisco Formation, Peru). Journal of Maps, 12:543-557. doi:10.1080/17445647.2015.1 048315

Bianucci, G. \& Landini, W. 2006. Killer sperm whale: a new basal physeteroid (Mammalia, Cetacea) from the Late Miocene of Italy. Zoological Journal of the Linnean Society, 148:103-131. doi:10.1111/j.1096-3642.2006.00228.x

Boersma, A.T \& Pyenson, N.D. 2015. Albicetus oxymycterus, a new generic name and redescription of a basal physeteroid (Mammalia, Cetacea) from the Miocene of California, and the evolution of body size in sperm whales. PLoS ONE, 10:e135551. doi:10.1371/journal.pone.0135551

Davies, J.L. 1963. The antitropical factor in cetacean speciation. Evolution, 7:107-116. doi:10.1111/j.1558-5646.1963.tb03258.x

Del Rio, C.J. 2004. Tertiary marine molluscan assemblages of eastern Patagonia (Argentina): a bioestratigraphic analysis. Journal of Paleontology, 78:1097-1122. doi:10.1017/S0022336000043912

Di Celma, C.; Malinverno, E.; Gariboldi, K.; Gioncada, A.; Rustichelli, A.; Pierantoni, P.; Landini, W.; Bosio, G.; Tinelli, C. \& Bianucci, G. 2016. Stratigraphic framework of the late Miocene to Pliocene Pisco Formation at Cerro Colorado (Ica Desert, Peru). Journal of Maps, 12:515-529. doi:10.1080/174 45647.2015.1047906

Fitzgerald, E.M.G. 2004. A review of the Tertiary fossil Cetacea (Mammalia) localities in Australia. Memoirs of Museum Victoria, 61:183-208. doi:10.24199/j.mmv.2004.61.12

Fitzgerald, E.M.G. 2011. A fossil sperm whale (Cetacea, Physeteroidea) from the Pleistocene of Nauru, equatorial 
southwest Pacific. Journal of Vertebrate Paleontology, 31:929931. doi:10.1080/02724634.2011.579670

Fordyce, R.E. \& Muizon, C. 2001. Evolutionary history of cetaceans: a review. In: J.-M. Mazin \& V. Buffrénil (eds.) Secondary adaptation of tetrapods to life in water, Verlag Dr. Friedrich Pfeil, p. 169-233.

Gondar, D. 1975. La presencia de cetáceos Physeteridae en el Terciario Superior ("Rionegrense") de la provincia de Río Negro. In: CONGRESO ARGENTINO DE PALEONTOLOGÍA Y BIOESTRATIGRAFÍA, 1, 1974. Atas, Tucumán, APA, p. 349-356.

Gutstein, C.; Horwitz, F.E.; Valenzuela-Too, A.M. \& FigueroaBravo, C.P. 2015. Cetáceos fósiles de Chile: contexto evolutivo y paleobiogeográfico. In: D. Rubilar-Rogers; R. Otero; A. Vargas \& M. Sallaberry (eds.) Vertebrados fósiles de Chile, Santiago, Museo Nacional de Historia Natural, p. 339-383 (Publicación Ocasional 63).

Hampe, O. 2006. Middle/late Miocene hoplocetine sperm whale remains (Odontoceti: Physeteridae) of North Germany with an emended classification of the Hoplocetinae. Fossil Record, 9:61-86. doi:10.1002/mmng.200600002

Heyning, J. \& Dahlheim, M. 1988. Orcinus orca. Mammalian Species, 304:1-9. doi:10.2307/3504225

Hirota, K. \& Barnes, L.G. 1994. A new species of Middle Miocene sperm whale of the genus Scaldicetus (Cetacea; Physeteridae) from Shigamura, Japan. Island Arc, 3:453-472. doi:10.1111/j.1440-1738.1994.tb00125.x

Kazár, E. 2002. Revised phylogeny of the Physeteridae (Mammalia: Cetacea) in the light of Placoziphius Van Beneden, 1869 and Aulophyseter Kellogg, 1927. Bulletin de l'Institut Royal des Sciences Naturelles de Belgique - Sciences de la Terre, 72:151-170.

Lambert, O.; Bianucci, G. \& De Muizon, C. 2016. Macroraptorial sperm whales (Cetacea, Odontoceti, Physeteroidea) from the Miocene of Peru. Zoological Journal of the Linnean Society (in press). doi:10.1111/zoj.12456
Lambert, O.; Bianucci, G.; Post, K.; De Muizon, C.; Salas-Gismondi, R.; Urbina, M. \& Reumer, J. 2010. The giant bite of a new raptorial sperm whale from the Miocene epoch of Peru. Nature, 466:105-108. doi:10.1038/nature09067

Pérez, L.; Cione, A.L.; Cozzuol, M. \& Varela, A.N. 2011. A Sperm Whale (Cetacea: Physeteroidea) from the Paraná Formation (Late Miocene) of Entre Ríos, Argentina. Environment and Taphonomy. Ameghiniana, 48:648-654. doi:10.5710/AMGH. v48i3(425)

Pilleri, G. \& Pilleri, O. 1982. Catalogue of the fossil odontocetes (Cetacea) in the Bologna Giovanni Capellini Museum of Palaeontology with description of a new species of Hoplocetus (Physeteridae). Padova, Istituti de Geologia e Minerologia dell'universita di Padova, p. 293-317. (Memoire 35).

Reichler, V.A. 2010. Estratigrafía y paleontología del Cenozoico marino del Gran Bajo y Salinas del Gualicho, Argentina, y descripción de 17 especies nuevas. Andean Geology, 37:177219. doi:10.4067/S0718-71062010000100008

Reumer, J.W.F.; Mens, T.H. \& Post, K. 2017. New finds of giant raptorial sperm whale teeth (Cetacea, Physeteroidea) from the Westerschelde Estuary (province of Zeeland, the Netherlands). Deinsea, 17:32-38.

Taylor, B.L.; Baird, R.; Barlow, J.; Dawson, S.M.; Ford, J.; Mead, J.G.; Sciara, G.N.D.; Wade, P. \& Pitman, R.L. 2013. Orcinus orca. In: The IUCN Red List of Threatened Species, e.T15421A50368125. doi:10.2305/IUCN.UK.2013-1.RLTS. T15421A44220470.en

Varola, A.; Landini, W. \& Pilleri, G. 1988. A new Scaldicetus (Cetacea: Physeteridae) from the Pietra leccese (Late Miocene). Investigations on Cetacea, 21:16-38.

Received in 10 April, 2018; accepted in 21 June, 2018. 